\title{
Folic acid - role in the body, recommendations and clinical significance
}

Kwas foliowy - rola w organizmie, rekomendacje i znaczenie kliniczne

Aneta Myszczyszyn ${ }^{1}$, Rafał Krajewski ${ }^{2}$ Monika Ostapów ${ }^{2}$, Lidia Hirnle ${ }^{1}$

\begin{abstract}
1I Department and Clinic of Gynaecology and Obstetrics, Wroclaw Medical University/
I Katedra i Klinika Ginekologii i Położnictwa, Uniwersytet Medyczny we Wrocławiu

Gynaecology and Obstetrics Interdisciplinary Students' Association, Wroclaw Medical Universit/ Interdyscyplinarne Studenckie Koło Naukowe Ginekologii i Położnictwa, Uniwersytet Medyczny we Wrocławiu
\end{abstract}

ORCID: Lidia Hirnle: 0000-0003-3138-7554

CORRESPONDING AUTHOR/AUTOR DO KORESPONDENCJI:

Aneta Myszczyszyn

I Katedra i Klinika Ginekologii i Położnictwa

Uniwersytet Medyczny we Wrocławiu

ul. T. Chałubińskiego 3, 50-368 Wrocław e-mail: aneta.myszczyszyn@gmail.com

STRESZCZENIE

Słowa kluczowe:

ABSTRACT

Key words:

\section{WWAS FOLIOWY - ROLA W ORGANIZMIE, REKOMENDACJE I ZNACZENIE KLINICZNE}

Wprowadzenie. Kwas foliowy jest związkiem zaliczanym do witamin z grupy B. W organizmie podlega procesom przekształcającym jego nieaktywną postać do formy odpowiedzialnej za biologiczne efekty działania kwasu foliowego, czyli 5-metylotetrahydrofolianu (5-MTHF). Odpowiada w szczególności za procesy prawidłowej biosyntezy zasad purynowych i pirydynowych biorących udział w tworzeniu cząsteczek DNA oraz RNA. Człowiek nie syntetyzuje endogennej formy kwasu foliowego, dlatego istotna jest suplementacja tej witaminy w formie naturalnej bądź preparatów wielowitaminowych. Najwięcej kwasu foliowego znajduje się w zielonych warzywach liściastych (szpinak, groch, szparagi) oraz w podrobach (wątróbka).W szczególności właściwa podaż kwasu foliowego jest wskazana u pacjentek ciężarnych, u których obserwuje się zmniejszoną ilość kwasu foliowego z powodu wykorzystania go przez intensywnie rozwijający się płód. Zalecaną dawką kwasu foliowego w tym okresie jest 0,4 mg/dobę i dawka ta zmienia się w zależności od historii chorobowej pacjentki i jej rodziny. Przedstawiono uaktualniony stan wiedzy dotyczący roli witaminy B9 w organizmie. Przeanalizowano znaczenie jej suplementacji w szczególnych sytuacjach klinicznych.

Podsumowanie. Wiele badań wskazuje na udział kwasu foliowego w zapobieganiu wrodzonym wadom układu nerwowego, sercow0-naczyniowego oraz moczowo-płciowego. Jego niedobór zwiększa ryzyko rozwoju powikłań w przebiegu ciąży, takich jak poronienia nawracające, stan przedrzucawkowy czy krwotok poporodowy. Rekomenduje się profilaktyczną suplementację kwasem foliowym, w szczególności wśród kobiet o podwyższonym ryzyku jego niedoboru.

kwas foliowy, rekomendacje, wady wrodzone, ciąża, suplementacja

\section{FOLIC ACID - ROLE IN THE BODY, RECOMMENDATIONS AND CIINICAL SIGNIFICANCE}

Introduction. Folic acid is a compound classified as B group vitamins. In the body it is subject to processes that transfer its inactive form into a form responsible for biological effects of folic acid, i.e. 5-methyltetrahydrofolate (5-MTHF). It is, in particular, responsible for processes of the correct biosynthesis of purine and pyridine bases present in the formation of DNA and RNA molecules. Humans do not synthesize the endogenous form of folic acid; therefore, it is vital to supplement this vitamin in its natural form or multivitamin preparations. The most folic acid is found in the green leafy vegetables (spinach, peas, asparagus) and in offal (liver). An adequate supply of folic acid is especially indicated in pregnant women with a reduced amount of folic acid due to its use by an intensively developing foetus. The recommended dose of folic acid during this period is $0.4 \mathrm{mg} / 24 \mathrm{~h}$ and this dose varies depending on the patient's and her family's medical history. The updated state of knowledge on the role of vitamin B9 in the body has been presented. The importance of its supplementation in specific clinical cases was analyzed.

Summary. Many studies indicate an important role of the folic acid in the prevention of congenital defects of the nervous, cardiovascular and urogenital systems. Its deficiency increases the risk of complications in pregnancy, such as recurrent miscarriages, pre-eclampsia or postpartum haemorrhage. For this reason, a prophylactic folic acid supplementation is recommended, in women with increased risk of its deficiency, in particular.

folic acid, recommendations, birth defects, pregnancy, supplementation 


\section{INTRODUCTION}

Pteroilomonoglutamic acid, also known as folic acid, belongs to the B group of vitamins (so-called folates). Folic acid itself is a vitamin B9 which chemical structure is formed by pteridine base, glutamic acid and p-aminobenzoic acid (PABA). Due to the lack of ability of animal cells to synthesize PABA, they are characterized by a low content of vitamin B9 in comparison with plant products where folic acid occurs in much higher concentrations. In food, vitamin B9 is found in the form of folates which are not so easily absorbed by the body. Appropriate enzymes, the so-called polyglutamylhydrolase, which are found in the epithelium of enterocytes, are necessary in this process. First, folic acid is reduced to dihydrofolate, and only in the second stage is dihydrofolate converted to tetrahydrofolate (THF). The condition for the occurrence of these reactions is a suitable environment, which consists of the dihydrofolate reductase enzyme and NAD$\mathrm{PH}+\mathrm{H}+$ and NADP + molecules. Dihydrofolate reductase is a key enzyme contributing to the formation of the active form of vitamin B9. Its activity may be inhibited by anticancer drugs, bactericidal antibiotics or antimalarial drugs. The last stage of folic acid metabolism is a reaction of THF transformation to 5-methyltetrahydrofolate (5-MTHF) catalyzed by methylenetetrahydrofolate reductase (MTHFR) enzyme. 5-MTHF is a derivative of THF, responsible for the biological effects of folic acid [1]. Thus, transformed folic acid is subject to the processes of absorption and addition of proteins in the bloodstream. It is transferred to all body tissues, but especially to those with a high proliferative potential, such as hematopoietic cells, digestive tract epithelium and foetal tissue. Every day an adult needs $400 \mathrm{ug}$ of folic acid [1]. However, during pregnancy or lactation this demand increases even twice as much. Folic acid is well absorbed from the gastrointestinal tract and its maximum concentration in the blood is observed within 2-3 hours of an oral vitamin intake. It is mainly excreted in faeces, to a lesser extent in urine. Abnormalities in the gene for the MTHFR enzyme result in an excess of inactive THF form in the body and this is one of the causes of the active form of folic acid deficiency.

\section{Study objective}

Analysis of the current state of knowledge regarding the role of folic acid in the body and its clinical significance based on bibliographic items, including recommendations of experts of the Polish Society of Gynecologists and Obstetricians (PTGiP) concerning vitamin B9 supplementation. Moreover, the determination of the recommendation and dosage of folic acid in selected clinical situations.

\section{METHODOLOGY}

The study was based on an overview of current bibliographic entries regarding the role of folic acid in the body and its clinical significance. Keywords selection is consistent with the current Medical Subject Heading (MeSH) list.

\section{The role of folic acid in the body}

The active form of folic acid (5-MTHF) and its derivatives are involved in numerous cellular reactions, the abnormal course of which directly translates into clinical aspects of some diseases. At the cellular level, 5-MTHF primarily participates in the transformation of amino acids such as serine or glycine [1]. Such biochemical processes enable another function of 5-MTHF, i.e. participation in the biosynthesis of nucleic acids. This is done through the synthesis of purines and pyrimidines that are essential elements of nucleic acids - RNA and DNA. However, the interaction of vitamin B9 with vitamin B12 is a guarantee of correct course of the processes presented. This is related to the fact that the presence of both vitamins makes it possible to maintain the continuity of homocysteine to methionine conversion processes and the conversion of 5-MTHF to THF. For this reason, vitamin B12 deficiency inhibits two reactions. The first is lack of homocysteine to methionine conversion which results in excess homocysteine, i.e. hyperhomocysteinemia. This condition is associated with a significantly increased risk of complicated pregnancy, such as recurrent miscarriages, intrauterine inhibition of foetal growth and pre-eclampsia [2]. The second reaction inhibited by vitamin B12 deficiency is 5-MTHF conversion to THF. The active form of folic acid is not converted to the inactive form, which results in an excess of 5-MTHF (active form) having a negative effect on the body [3]. Excessive concentration of 5-MTHF predisposes to the development of diabetes in pregnant women and may affect the low birth weight in a newborn [3]. Numerous functions that folic acid plays in the human body clearly indicate the need for its daily intake, either in its natural form or in the form of supplements. Humans and other animals synthesize small amounts of endogenous folic acid. This is done through the saprophytic flora of the small intestine. However, it should be mentioned that not only is the folic acid supplementation indispensable for the proper body function but also provision of appropriate concentrations of vitamin B12 is a guarantee of biochemical processes at the cellular level continuity. Vitamin B9 deficiency translates into the development of some diseases, in particular megaloblastic anaemia, colorectal cancer, foetal dysraphic defects, neurodegenerative diseases and cardiovascular diseases.

\section{Folic acid presence in food}

Folates can be found in both plant and animal products. In the plant products category, green leafy vegetables lead the way. Among them, spinach (131 ug/100 $\mathrm{g})$, peas (105 ug/100 g) and asparagus (89 ug/100 g) are ranked the highest. In cereal products, most folic acid is found in cereal flakes $(100 \mathrm{ug} / 100 \mathrm{~g})$. In animal products, on the other hand, most folates are found in the bovine liver $(215 \mathrm{ug} / 100 \mathrm{~g})$. The original amounts of folates in products become significantly reduced as a result of heat treatment. One hard-cooked chicken egg has only $22 \mathrm{ug}$, while cooked fish has 12 ug of folic acid [4]. Moreover, other factors influencing the vitamin B9 assimilation include the way of consuming products (raw, cooked), the form of folates in food, gastrointestinal tract diseases, 
and the type of drugs taken. For this reason, the body can assimilate lower folate concentrations than their supply and therefore, the values of folic acid often do not correspond to real demand of the body.

\section{Folic acid supplementation}

According to recommendation of the Polish Society of Gynaecologists and Obstetricians (PTGiP), every woman of childbearing age should follow a diet whose products contain significant amounts of vitamin B9. Moreover, PTGiP also recommends consumption of the so-called fortified food. Additional supplementation with multivitamin preparations of proven composition and effect [2], including folates, should be used in particular by women in the procreation period, planning pregnancies, being pregnant, during confinement or breastfeeding. The essence of folic acid supplementation during this period is to minimize the risk of dysraphic defects in the foetus and cleft palate and/or lip. Depending on the patient and her family's medical history, between low, intermediate and high-risk groups of nervous system defects in the foetus can be distinguished. The folic acid supplementation in individual groups varies and depends on the above medical history of a mother and her family. Folate supplementation in the low-risk group concerns patients who, based on their history, were not diagnosed with diseases affecting folic acid metabolism, foetal malformations and complications during pregnancy. For this reason, the use of folic acid preparations in this group of women is recommended at a dose of $0.4 \mathrm{mg} / 24 \mathrm{~h}$ for at least 12 weeks before conception, followed by continuation of supplementation during pregnancy, puerperium and lactation [2]. In the case of women from a group of indirect risk, folate supplementation concerns patients in whom, on the basis of the patient's or family's history, the presence of diseases affecting folic acid metabolism, foetal malformation or pregnancy complications (preeclampsia, intrauterine inhibition of foetal growth) was found. These conditions affecting folic acid metabolism also include prepregnancy diabetes type 1 or type 2 , gastrointestinal diseases such as inflammatory bowel disease, coeliac disease, liver failure, dialysis, obesity, mutations in the MTHFR gene or drugs taken - metformin, methotrexate, cholestramine, sulfasalazine, antiepileptic drugs. For this reason, the use of folic acid preparations in this group of women is recommended at a dose of $0.8 \mathrm{mg} / 24 \mathrm{~h}$ for at least 12 weeks before conception, followed by continuation of supplementation during pregnancy, puerperium and lactation. Additionally, active folates and vitamin B12 supply is recommended [2]. In the case of a high-risk group, however, neural tube defects occur in the mother, father or their offspring. Women who qualify to this group are recommended to take folic acid preparations at a dose of $5 \mathrm{mg} / 24 \mathrm{~h}$ (including active folates) and vitamin B12 in the preconceptional period and the 1st trimester of pregnancy. In the 2 nd and 3 rd trimesters and in the lactation period, the dose of folic acid should be reduced to $0.8 \mathrm{mg} / 24 \mathrm{~h} \mathrm{[2]}$. The significant role of folic acid in the prevention of nervous system defects is confirmed by the results of the Kerr et al. They observed that pregnant women who reported fever within 28 days before and 28 days after the last menstrual period were associated with a 2.4 times higher risk of neural tube defects compared to pregnant women who did not report fever within this period of OR (95\% CI: 1.5-4.0). Moreover, their results showed that daily folic acid dose of $0.4 \mathrm{mg} / 24 \mathrm{~h}$ was associated with a lower risk of nervous system defects in patients reporting fever in the periconceptional period [5].

\section{Specific situations}

\section{Pregnant women with epilepsy}

Special attention should be paid to epileptic patients of childbearing age who suffer from epilepsy and are therefore taking antiepileptic drugs. Studies show that $63 \%$ of women with epilepsy during pregnancy do not experience any changes in the course of epilepsy, $17 \%$ of cases increase the frequency of attacks, and $16 \%$ decrease the frequency [6]. However, lack of relevant control of epilepsy during pregnancy is associated with an increased risk of complications for both mother and foetus. A special situation is the generalised tonic-clonic seizures occurrence in the mother, in the course of which a decrease in the blood flow volume through the placenta is observed. Foetal hypoxia and development of lactate acidosis is the consequence of such situation [6]. Maternal complications include an increase in the risk of miscarriage, preterm birth, development of hypertension or postnatal haemorrhage [7]. These are the reasons why all women with epilepsy in the reproductive age should be under proper medical treatment. However, the therapeutic management in this group of patients is difficult. This is due to the teratogenic effect of many antiepileptic drugs during pregnancy, especially until the 4 th week, when the embryonic cells intensively proliferate and are the most likely to be destroyed by exogenous factors during this period. The fact that some women learn about pregnancy at the end of neurogenesis is an additional aspect that hinders proper behaviour. The reason for this phenomenon may also be the contraception failure. Studies indicate that the use of antiepileptic drugs may present the cause of reduced effectiveness of hormonal contraception [8]. This is probably due to the mechanism of these drugs activation in the liver. Drugs such as phenytoinum, phenobarbital, primidone, carbamazepine or felbamate are enzymatically activated which results in an increase in the metabolism of hormones supplied in contraception products [6]. Drugs such as levetiracetam or lamotrigine on the other hand, are non-enzymatic and thus theoretically associated with less effect on the effectiveness of hormonal contraception. It has been observed that simultaneous administration of hormonal contraceptives and lamotrigine reduces its concentration in the mechanism of glucuronization induced by ethinylestradiolum [6]. This implies that lamotrigine has a minor effect on the hormonal contraception effectiveness [8]. Moreover, the concentration of folic acid in the mother's blood during pregnancy decreases, and the antiepileptic drugs used by the mother intensify this effect [6]. Therefore, it is recommended to take folic acid preparations at a dose of 0.4-5 mg/day in all women with epilepsy during the reproductive age, before conception 
in particular [6]. Unfortunately, there is no clear position on the recommended dose of vitamin B9. However, some authors believe that higher doses of folic acid should be supplemented when a patient takes drugs such as valproic acid or carbamazepine since they are associated with a significant impact on the development of congenital defects of the nervous system [6]. Proper supplementation with folic acid is associated with a reduced risk of development of dysraphic defects in the foetus [9]. It should be emphasized however, that $70 \%$ these defects are of genetic origins and the use of exogenous vitamin B9 is aimed at reducing the risk of congenital defects of the nervous system by influencing epigenetics [9].

\section{Women with a mutation in the MTHFR gene}

The MTHFR gene is located at the chromosome 1 loci 1p36.3. It codes the methylenetetrahydrofolate reductase proteins (MTHFR). It is an enzyme necessary to transform folic acid into its active form, i.e. 5-methyltetrahydrofolate (5-MTHF). Many different polymorphisms of the MTHFR gene are known which are found in $8-18 \%$ patients in Europe and 5-11\% in Poland [2]. Mutations of the MTHFR gene (mainly in homozygote) are the cause of abnormal enzyme activity, which in turn is associated with deficiency of the active form of vitamin B9. Moreover, the concentration of homocysteine increases, the excess of which is the cause of complications not only in pregnancy, but also in the cardiovascular system. The most common mutation is cytosine (C) transition to thymine ( $\mathrm{T}$ ) in 677 position, which leads to the substitution of valence for alanine and thus produces an abnormal product in the MTHFR gene. The problem of the mentioned mutation concerns women of childbearing age in particular, since the folic acid preparations taken by them do not undergo sufficient transformation into active forms. As a result, they may experience weakness and fatigue and show symptoms associated with sleeping disorders. Despite folate supplementation, we observe low concentrations of folic acid in this group of patients. Therefore, the risk of congenital nervous system defects occurrence in their offspring significantly increases [10]. The Servy et al. study compared the efficacy of high-dose folic acid therapy $(5 \mathrm{mg} / 24 \mathrm{~h})$ and 5-methyltetrahydrofolate (5-MTHF; $800 \mathrm{ug} / 24 \mathrm{~h}$ ) among 30 pairs in which at least one partner revealed the MTHFR gene mutation. The results clearly demonstrated the benefits of 5-MTHF supplementation compared to folic acid. In the course of 5-MTHF treatment covering a 4-month period, no adverse reactions were observed in the study group. The effects of the study were the result of 5-MTHF omitting the folate activation pathway by the MTHFR enzyme, which in the case of the study group was abnormal. Moreover, the use of 5-MTHF was not associated with the risk of complications associated with the so-called unmetabolized folic acid (UMFA), such as dysfunction of the immune system or increased risk of colorectal and prostate cancer [11]. Therefore, 5-MTHF preparations are recommended in the group of patients with mutation in the MTHFR gene.

\section{Folic acid deficiency and excess in the body}

Folate deficiencies in the daily diet increase the risk of numerous pathologies development, including atherosclerosis, cardiovascular diseases, megaloblastic anaemia, cancers and neurodegenerative diseases. In obstetrics they are mainly connected with the risk of recurrent miscarriages, preeclampsia or preterm birth. However, the most important consequence of folic acid deficiency in the procreation age is an increase in the risk of congenital malformations, not only of the nervous system, but also of the cardiovascular or urogenital system. Nevertheless, it should be stressed that too high doses of folic acid may also have a negative impact on the body. Increased doses of folic acid can cause insomnia, irritation, depression, skin allergic reactions or gastrointestinal disorders. Many studies have highlighted the potential effects of folic acid supplemented during pregnancy on respiratory diseases. Whitrow et al. presented the results of studies in which the supply of folic acid during pregnancy was associated with a significantly higher risk of asthma development in children aged 3.5 years and 5.5 years [12]. On the other hand, the studies of Trivedi et al. proved the lack of correlation between folic acid intake during pregnancy and the increased risk of asthma development in childhood [13]. Similar conclusions have been reached in their study by Vereen et al., who did not present a link between the measured level of folic acid in the second trimester of pregnancy and the increased risk of respiratory diseases [14]. The above data inconclusively assess the influence of vitamin B9 on the development of respiratory diseases. For this reason, such studies should be continued in order to clarify the recommendations for folic acid supplementation during pregnancy.

\section{The nervous system}

Increased demand for folic acid occurs especially during pregnancy and lactation. Therefore, recommendations indicate that supplementation with folic acid should start as early as 12 weeks before the planned conception. Insufficient supply of folates may be the cause of congenital malformations in the foetus. They are the result of abnormal DNA biosynthesis, without which no cell can complete its metabolic cycle, including division and differentiation. It should be mentioned that not only insufficient supply in the daily diet, but also inadequate bioavailability and genetically determined abnormalities in metabolism lead to shortages of folates. The effect of folic acid on the decrease in the incidence of dysraphic defects is significant $[15,16]$. They result from abnormal closure of the neural tube in the embryonic period, which occurs during early pregnancy (3-4 weeks). It is also a "hot period" when women do not know or only learn about pregnancy. Starting folic acid supplementation at this time reduces the chance of avoiding the development of nervous system defects in the foetus. For this reason, earlier vitamins supplementation, especially folates, is so crucial. It is estimated that in Poland the incidence of dysraphic defects is 2-3 cases per 1000 births. However, these are epidemiological data primarily related to spinal hernias and cerebral hernias [17]. One of the most serious 
defects of the neural tube is brainlessness which leads to foetal death. On the other hand, the most common defect of the nervous system is spina bifida associated with many complications for the child, consequently leading to permanent disability. Poland has the highest mortality rate due to congenital neural tube defects compared to Europe. At the same time, it is a signal to take more intensive action to improve the epidemiological situation. Own surveys conducted in Poland from January to April 2018 were aimed at illustrating the current state of knowledge of young women about the necessity of folic acid supplementation. A questionnaire prepared by the researchers was distributed through social media. The survey covered a total of 961 respondents, the most numerous of whom were women aged $18-25(80 \%)$. In response to a question about the recommended folic acid dose, less than $38 \%$ respondents indicated the correct dose of $0.4 \mathrm{mg} / 24 \mathrm{~h}$. The next question referred to the period when a woman should supplement her folate. Only half of women knew when to supplement folic acid. Moreover, $72 \%$ women do not use the recommended dose of vitamin B9 during the reproductive period. The only $34 \%$ respondents know that one of the factors to influence the reduction of vitamin B9 level in the body is the use of oral contraceptives. The above data unequivocally indicate insufficient knowledge of young Polish women in the field of folate supplementation. On the one hand, this is due to the lack of proper dissemination of information on the folic acid effectiveness in the prevention of congenital malformations. Whereas on the other hand, some preparations available on the pharmaceutical market do not contain appropriate doses of vitamin composition. In some countries folic acid is obligatorily added to food, e.g. bread, which is a justified prophylaxis of congenital developmental defects, especially dysraphic defects. In Poland, too many women still learn about the necessity of supplementation only from their physician and it is usually too late to minimize the risk of nervous system defects. For this reason, it is crucial to disseminate information about the positive effects of regular and daily use of folic acid, especially among young women at reproductive age. Folic acid belongs to vitamins and should be used regardless of the type of woman's diet since it is an essential element for the any cell efficient functioning in the body. Despite numerous studies and surveys on the proper supplementation of folic acid in Poland, the knowledge concerning this subject is still unsatisfactory. Indirectly, this may translate into the frequency of congenital defects of the nervous system in our country. On this basis, a decision to conduct further surveys seems justified.

\section{Cardiovascular system}

The protective effect of folic acid is not only related to the nervous system. Studies also indicate contribution of vitamin B9 in prevention of congenital heart defects $[18,19]$. Congenital heart defects (CHDs) are among the most common congenital defects worldwide and their prevalence is estimated at 0.6-1.9 per 100 newborns [20]. Extensive analysis performed by Ingrid et al. proved that folic acid intake by women in the peri-conceptual period was associated with a $20 \%$ lower risk of developing CHDs in their offspring. In particular, it concerned ventricular septal defect (VSD) and atrial septal defect (ASD) [20].

\section{Urogenital system}

The effect of vitamin B9 on the prevention of the urinary tract malformations on the other hand, proves inconclusive. Some studies show that folic acid supplementation increases the risk of their development. The Groen in 't Woud et al. questionnaire among 562 parents of children with congenital urinary tract defects and 2139 parents of healthy children indicates that folic acid may be a risk factor for the development of urinary tract defects, in particular for the duplication of pelvicalyceal system and vesicoureteral reflux [21]. However, it should be stressed that the above dependencies have been related to women's intake of folic acid bound or not bound with multivitamin preparations. The same study showed that taking only multivitamins without additional supplementation with folic acid is associated with a slight reduction in the risk of congenital malformations of the urinary system. In turn, the study by Canfield et al. showed no negative influence of folic acid taken by women (not in multivitamin form) on the development of urinary tract defects [22]. In their study, Godwin et al. noted an increase in the incidence of obstructive malformations of the urogenital system in children of women consuming products enriched with folic acid [23].

\section{Other congenital defects}

Furthermore, it is believed that proper supplementation with folic acid may reduce the risk of giving birth to a child with cleft facio-cranial bones. There are also reports indicating the role of folic acid in the prevention of limb defects, congenital anal overgrowth, congenital pyloric stenosis, hypospadias, polylactylia or syndactylia.

\section{SUMMARY}

It is recommended to administer folic acid in a natural way (products containing vitamin B9) or in multivitamin supplements due to its insufficient synthesis in cells. In order to minimize occurrence of congenital defects of the nervous system, PTGiP recommends the supplementation of folic acid at a dose of $0.4 \mathrm{mg} /$ day to all women in the reproductive period at least 12 weeks before conception, and then during the whole pregnancy and lactation. In pregnant women suffering from epilepsy, supplementation with higher doses of folates is recommended and the doses depend on the antiepileptic drugs taken by the patient. Women with MTHFR gene mutation should use active forms of folic acid, such as 5-MTHF. The clinical relevance of folic acid is primarily reduction of the risk of congenital developmental defects of the nervous, cardiovascular and urogenital systems. However, there are reports of its adverse effects, including the respiratory system (predisposes to the occurrence of asthma). 


\section{Kwas foliowy - rola w organizmie, rekomendacje i znaczenie kliniczne}

\section{WPROWADZENIE}

Kwas pteroilomonoglutaminowy inaczej zwany kwasem foliowym należy do witamin z grupy B (tzw. folianów). Sam kwas foliowy to witamina B9, któregostrukturę chemiczną tworzą zasada pterydynowa, kwas glutaminowy oraz kwas p-aminobenzoesowy (PABA). Z uwagi na brak zdolności komórek zwierzęcych do syntezy PABA cechują się one niewielką zawartością witaminy $\mathrm{B} 9 \mathrm{w}$ porównaniu $\mathrm{z}$ produktami roślinnymi, $\mathrm{w}$ których kwas foliowy występuje w zdecydowanie większych stężeniach. W pożywieniu witamina B9 występuje pod postacią folianów, które nie są tak łatwo przyswajalne przez organizm. W procesie tym niezbędne są odpowiednie enzymy tzw. poliglutamylohydrolazy, które znajdują się w nabłonku enterocytów. W pierwszej kolejności kwas foliowy ulega redukcji do dihydrofolianu, a dopiero $\mathrm{w}$ drugim etapie dihydrofolian jest przekształcany do tetrahydrofolianu (THF). Warunkiem zaistnienia tych reakcji jest odpowiednie środowisko, które składa się z enzymu reduktazy dihydrofolianowej oraz cząsteczek $\mathrm{NADPH}+\mathrm{H}+\mathrm{i} \mathrm{NADP}+$. Reduktaza dihydrofolianowa jest kluczowym enzymem przyczyniającym się do powstawania aktywnej formy witaminy B9. Jego aktywność może być hamowana przez leki przeciwnowotworowe, antybiotyki bakteriobójcze czy leki przeciwmalaryczne. Ostatni etap metabolizmu kwasu foliowego stanowi reakcja przekształcenia THF do 5-metylotetrahydrofolianu (5-MTHF) katalizowanej przez enzym reduktazę metylenotetrahydrofolianową (MTHFR). 5-MTHF jest pochodną THF, która odpowiada za biologiczne efekty kwasu foliowego [1]. Tak przekształcony kwas foliowy podlega procesom wchłaniania i addycji z białkami w krwiobiegu. Przenoszony jest do wszystkich tkanek organizmu, a w szczególności do tych, które charakteryzują się wysokim potencjałem proliferacyjnym, jak komórki układu krwiotwórczego, nabłonka przewodu pokarmowego oraz tkanki płodu. Dziennie dorosły człowiek potrzebuje 400ug kwasu foliowego [1]. Jednak w okresie ciąży czy laktacji zapotrzebowanie to wzrasta nawet dwukrotnie. Kwas foliowy dobrze wchłania się z przewodu pokarmowego, a jego maksymalne stężenie we krwi obserwuje się w ciągu 2-3 godzin od doustnego przyjęcia witaminy. Wydalany jest głównie wraz z kałem, w mniejszym stopniu $\mathrm{z}$ moczem. Nieprawidłowości w genie dla enzymu MTHFR skutkują nadmiarem nieaktywnej formy THF w organizmie i jest to jedna z przyczyn niedoboru aktywnej formy kwasu foliowego.

\section{CEL PRACY}

Analiza aktualnego stanu wiedzy o roli kwasu foliowego w organizmie oraz jego znaczenia klinicznego w oparciu o pozycje bibliograficzne, w tym między innymi rekomendacje ekspertów Polskiego Towarzystwa Ginekologów i Położników (PTGiP) dotyczące suplementacji witaminy B9. Ponadto określenie wskazań i dawkowania kwasu foliowego w wybranych sytuacjach klinicznych.

\section{Metodologia}

Praca powstała w oparciu o przegląd aktualnych pozycji bibliograficznych dotyczących roli kwasu foliowego w organizmie oraz jego znaczenia klinicznego. Dobór słów kluczowych jest zgodny z aktualną listą Medical Subject Heading (MeSH).

\section{Rola kwasu foliowego w organizmie}

Aktywna forma kwasu foliowego (5-MTHF) oraz jej pochodne biorą udział w licznych reakcjach komórkowych, których nieprawidłowy przebieg bezpośrednio przekłada się na aspekty klinicznego występowania niektórych chorób. Na poziomie komórkowym 5-MTHF uczestniczy przede wszystkim w przemianie takich aminokwasów, jak seryna czy glicyna [1]. Takie procesy biochemiczne umożliwiają pełnienie przez 5-MTHF kolejnej funkcji, jaką jest udział w biosyntezie kwasów nukleinowych. Dzieje się to za pośrednictwem syntezy puryn i pirymidyn, które są nieodzownymi elementami wchodzącymi w skład kwasów nukleinowych - RNA i DNA. Jednak gwarantem prawidłowego przebiegu przedstawionych procesów jest współdziałanie witaminy B9 $\mathrm{z}$ witamina B12. Jest to związane $\mathrm{z}$ faktem, że obecność obu witamin umożliwia zachowanie ciągłości procesów przekształcania homocysteiny do metioniny oraz przemiany 5-MTHF do THF. Z tego powodu niedobór witaminy B12 powoduje zahamowanie dwóch reakcji. Pierwszą z nich jest brak przekształcenia homocysteiny do metioniny. Skutkiem tego jest nadmiar homocysteiny, czyli hiperhomocysteinemia. Taki stan wiąże się z istotnie zwiększonym ryzykiem powikłań w ciąży, jak poronienia nawracające, wewnątrzmaciczne zahamowanie wzrastania płodu oraz stan przedrzucawkowy [2]. Drugą reakcją hamowaną przez niedobór witaminy B12 jest przekształcenie 5-MTHF do THF. Aktywna postać kwasu foliowego nie ulega konwersji do formy nieaktywnej, co w konsekwencji powoduje nadmiar 5-MTHF (formy aktywnej) mającej negatywny wpływ na organizm [3]. Zbyt wysokie stężenie 5-MTHF predysponuje do rozwoju cukrzycy ciężarnych oraz może mieć wpływ na niską masę urodzeniową noworodka [3]. Liczne funkcje, jakie odgrywa kwas foliowy w organizmie człowieka jednoznacznie wskazują na potrzebę jego codziennego przyjmowania albo w postaci naturalnej albo w postaci suplementów. Człowiek oraz inne zwierzęta syntetyzują niewielkie ilości endogennego kwasu foliowego. Odbywa się to za pośrednictwem saprofitycznej flory jelita cienkiego. Jednak należy nadmienić, że nie tylko suplementacja kwasu 
foliowego jest niezbędna do właściwego funkcjonowania organizmu, ale również dostarczenie odpowiednich stężeń witaminy B12 jest gwarantem zapewnienia ciągłości procesów biochemicznych na poziomie komórkowym. Niedobór witaminy B9 przekłada się na rozwój niektórych chorób, a w szczególności niedokrwistości megaloblastycznej, raka jelita grubego, wad dysraficznych płodu, chorób neurodegeneracyjnych oraz układu sercowonaczyniowego.

\section{Występowanie kwasu foliowego w żywności}

Foliany są obecne w produktach roślinnych i zwierzęcych. W kategorii produktów roślinnych prym wiodą zielone warzywa liściaste. Wśród nich najwyżej klasyfikuje się szpinak (131ug/100g), groch (105ug/100g) i szparagi $(89 \mathrm{ug} / 100 \mathrm{~g})$. W produktach zbożowych najwięcej kwasu foliowego znajduje się w płatkach zbożowych (100ug/100g). Z kolei w produktach zwierzęcych najwięcej folianów znajduje się w wołowej wątrobie (215ug/100g). Pierwotne ilości folianów znajdujące się w produktach ulegają znacznej redukcji wskutek ich obróbki termicznej. Jedno jajo kurze gotowane na twardo to już tylko $22 \mathrm{ug}$, zaś gotowana ryba to $12 \mathrm{ug}$ kwasu foliowego [4]. Ponadto innymi czynnikami wpływającymi na przyswajalność witaminy B9 to sposób spożywania produktów (surowe, gotowane), postać folianów w pokarmie, choroby układu pokarmowego, rodzaj stosowanych leków. Z tego powodu organizm może przyswajać mniejsze stężenia folianów niż wynikałoby to $\mathrm{z}$ ich podaży i dlatego często wartości kwasu foliowego nie pokrywają się z realnym zapotrzebowaniem organizmu.

\section{Suplementacja kwasu foliowego}

Według rekomendacji Polskiego Towarzystwa Ginekologów i Położników (PTGiP) każda kobieta w wieku rozrodczym powinna stosować dietę, której produkty zawierają znaczne ilości witaminy B9. Ponadto PTGiP zaleca również stosowanie tzw. żywności fortyfikowanej. Dodatkową suplementację preparatami wielowitaminowymi o udowodnionym składzie oraz działaniu [2], w tym folianami, powinny stosować w szczególności kobiety w okresie prokreacyjnym, planujące ciąże, będące w ciąży, w czasie połogu lub karmiące piersią. Istotą suplementacji kwasu foliowego w tym okresie jest zminimalizowanie ryzyka wystąpienia wad dysraficznych u płodu oraz rozszczepu podniebienia i/lub wargi. W zależności od historii chorobowej pacjentki i jej rodziny można wyróżnić grupy niskiego, pośredniego i wysokiego ryzyka występowania wad układu nerwowego u płodu. Suplementacja kwasem foliowym w poszczególnych grupach jest inna i zależy od wspomnianego wywiadu chorobowego matki i jej rodziny. Suplementacja folianów w grupie niskiego ryzyka dotyczy pacjentek, u których na podstawie wywiadu nie stwierdzono występowania schorzeń wpływających na metabolizm kwasu foliowego, wad płodu oraz powikłań w ciąży. Z tego powodu przyjmowanie preparatów kwasu foliowego w tej grupie kobiet zaleca się minimum na 12 tygodni przed poczęciem w dawce $0,4 \mathrm{mg} /$ dobę, a następnie kontynuację suplementacji w czasie ciąży, połogu i laktacji [2]. W przypadku kobiet z grupy pośredniego ryzyka suplementacja folianów dotyczy pacjentek, u których na podstawie wywiadu dotyczącego samej pacjentki lub wywiadu rodzinnego stwierdzono obecność schorzeń wpływających na metabolizm kwasu foliowego, wady płodu lub powikłania w ciąży (stan przedrzucawkowy, wewnątrzmaciczne zahamowanie wzrastania płodu).Do wspomnianych schorzeń wpływających na metabolizm kwasu foliowego zalicza się także cukrzycę przedciążową typu 1 lub typu 2, choroby układu pokarmowego, jak nieswoiste zapalenia jelit, celiakia, niewydolność wątroby, dializoterapie, otyłość, mutacje w genie MTHFR czy stosowane leki - metformina, metotreksat, cholestyramina, sulfasalazyna, leki przeciwpadaczkowe. $Z$ tego powodu przyjmowanie preparatów kwasu foliowego w tej grupie kobiet zaleca się w dawce $0,8 \mathrm{mg} /$ dobę przez okres co najmniej 12 tygodni przed poczęciem, a następnie kontynuację suplementacji w czasie ciąży, połogu i laktacji. Dodatkowo zaleca się podaż aktywnych folianów oraz witaminy B12 [2]. Natomiast kobietom z grup wysokiego ryzyka (występowanie wad cewy nerwowej w rodzinie) zaleca się dawkę $5 \mathrm{mg} /$ dobę kwasu foliowego (uwzględniając aktywne foliany) oraz witaminę B12w okresie przedkoncepcjnym i I trymestru ciąży. Dawkę kwasu foliowego do $0,8 \mathrm{mg} /$ dobę należy zmniejszyć po 12 tygodniu ciąży (II i III trymestr), jak również w okresie laktacji [2]. O znaczącej roli kwasu foliowego w prewencji wad układu nerwowego świadczą wyniki badania Kerr i wsp. Zaobserwowali bowiem, że ciężarne zgłaszające gorączkę w okresie 28 dni przed i 28 dni po dniu ostatniej miesiączki były związane z 2,4 razy większym ryzykiem wystąpienia wad cewy nerwowej w porównaniu do ciężarnych nie zgłaszających gorączki w tym okresie. Ponadto ich wyniki pokazały, że codzienne przyjmowanie kwasu foliowego w dawce 0,4 mg/dobę wiązało się z mniejszym ryzykiem wystąpienia wad układu nerwowego u pacjentek zgłaszających gorączkę w okresie okołokoncepcyjnym [5].

\section{Sytuacje szczególne}

\section{Kobiety $w$ ciąży chorujące na epilepsje}

Szczególną uwagę należy zwrócić na pacjentki w wieku rozrodczym chorujące na padaczkę i przyjmujące $\mathrm{z}$ tego powodu leki przeciwpadaczkowe. Badania wskazują, że $63 \%$ kobiet chorujących na padaczkę w okresie ciąży nie doznaje zmian w jej przebiegu, w 17\% przypadków częstość ataków zwiększa się, a w 16\% ulegają one zmniejszeniu [6]. Jednak brak odpowiedniej kontroli epilepsji w okresie ciąży wiąże się ze wzrostem ryzyka powikłań zarówno dla matki, jak i płodu. Szczególną sytuacją są występujące u matki uogólnione napady toniczno-kloniczne, w przebiegu których obserwuje się zmniejszenie objętości krwi przepływającej przez łożysko. Konsekwencją takiej sytuacji jest niedotlenienie płodu i rozwój kwasicy mleczanowej [6]. Z kolei wśród powikłań matczynych wymienić należy wzrost ryzyka poronienia, porodu przedwczesnego, rozwoju nadciśnienia tętniczego czy krwotoku poporodowego [7]. Są to powody, dla których wszystkie kobiety w okresie rozrodczym chorujące na padaczkę powinny być objęte prawidłowym leczeniem. Niemniej postępowanie terapeutyczne w tej grupie pacjentek jest 
trudne. Wynika to $\mathrm{z}$ teratogennego działania wielu leków przeciwpadaczkowych w okresie ciąży, a w szczególności do 4. tygodnia, kiedy komórki zarodka intensywnie proliferują i są w tym okresie najbardziej narażone na destrukcję przez czynniki egzogenne. Dodatkowym aspektem utrudniającym właściwe postępowanie jest fakt, że część kobiet dowiaduje się o ciąży w momencie zakończenia neurogenezy. Przyczyną tego zjawiska może być również niepowodzenie antykoncepcji. Badania wskazują, że stosowanie leków przeciwpadaczkowych może być przyczyną zmniejszonej skuteczności antykoncepcji hormonalnej [8] Wynika to prawdopodobnie $\mathrm{z}$ mechanizmu aktywacji tych leków w wątrobie. Leki, jak fenytoina, fenobarbital, prymidon, karbamazepina czy felbamat ulegają enzymatycznej aktywacji, która skutkuje wzrostem metabolizmu hormonów dostarczanych w preparatach antykoncepcyjnych [6]. Z kolei leki, jak lewetiracetam czy lamotrygina podlegają nieenzymatycznej aktywacji, a zatem teoretycznie wiążą się z mniejszym wpływem na skuteczność antykoncepcji hormonalnej. Zaobserwowano, że jednoczesne przyjmowanie preparatów antykoncepcji hormonalnej oraz lamotryginy zmniejsza jej stężenie w mechanizmie glukuronizacji indukowanej etynyloestradiolem [6]. Wynika z tego, że lamotrygina wywiera niewielki wpływ na skuteczność antykoncepcji hormonalnej [8]. Ponadto w okresie ciąży stężenie kwasu foliowego we krwi matki zmniejsza się, a stosowane przez nią leki przeciwpadaczkowe nasilają ten efekt [6]. Z tego powodu u wszystkich kobiet $\mathrm{w}$ okresie rozrodczym chorujących na padaczkę zaleca się przyjmowanie preparatów kwasu foliowego w dawce 0,4-5 mg/dobę, a w szczególności przed poczęciem [6] Niestety nie ma jednoznacznego stanowiska, co do rekomendowanej dawki witaminy B9. Jednak część autorów uważa, że większe dawki kwasu foliowego należy suplementować w przypadku stosowania przez pacjentkę leków, jak kwas walproinowy lub karbamazepina albowiem są one związane $\mathrm{z}$ istotnym wpływem na rozwój wrodzonych wad układu nerwowego [6]. Prawidłowa suplementacja kwasem foliowym wiąże się ze zmniejszonym ryzykiem rozwoju wad dysraficznych u płodu [9]. Należy jednak podkreślić, że $70 \% \mathrm{z}$ tych wad ma podłoże genetyczne, a stosowanie egzogennej witaminy B9 ma na celu zmniejszenie ryzyka wystąpienia wrodzonych wad układu nerwowego poprzez wpływ na epigentykę [9].

\section{Kobiety $z$ mutacja $w$ genie MTHFR}

Gen MTHFR jest zlokalizowany na chromosomie 1 w locus 1p36.3.Koduje on białko reduktazę metylenotetrahydrofolianową (MTHFR). Jest to enzym niezbędny to przekształcenia kwasu foliowego do jego aktywnej formy, czyli 5-metylotetrahydrofolianu (5-MTHF). Znanych jest wiele różnych polimorfizmów genu MTHFR, które stwierdza się u 8-18\% pacjentek w Europie i 5-11\% w Polsce [2]. Mutacje genu MTHFR (głównie u homozygot) są przyczyną nieprawidłowej aktywności enzymu, co z kolei wiąże się z niedoborem aktywnej formy witaminy B9. Ponadto wzrasta stężenie homocysteiny, której nadmiar jest przyczyną powikłań nie tylko w ciąży, ale również ze strony układu sercowo-naczyniowego. Najczęściej spotykaną mutacją jest tranzycja cytozyny (C) na tyminę
(T) w pozycji 677, która prowadzi do substytucji alaniny waliną i w ten sposób powstaje nieprawidłowy produkt genu MTHFR. Problem wspomnianej mutacji dotyczy w szczególności kobiet w wieku rozrodczym. Bowiem przyjmowane przez nie preparaty kwasu foliowego nie ulegają dostatecznej przemianie do form aktywnych. W związku z tym mogąone odczuwać osłabienie i zmęczenie oraz prezentować objawy związane z zaburzeniami snu. Mimo suplementacji folianów w tej grupie pacjentek obserwujemy niskie stężenia kwasu foliowego. Zatem ryzyko pojawienia się u ich potomstwa wrodzonych wad układu nerwowego istotnie wzrasta [10]. W badaniu Servy i wsp. porównano skuteczność terapii kwasem foliowym w wysokich dawkach (5 mg/dobę) oraz 5-metylotetrahydrofolianem (5-MTHF; 800ug/dobę) wśród 30 par, w których co najmniej jeden partner/ka miała mutację w genie MTHFR. Wyniki jednoznacznie udowodniły korzyści związane $\mathrm{z}$ suplementacją 5-MTHF w porównaniu z kwasem foliowym. W przebiegu leczenia 5-MTHF obejmującym okres 4 miesięcy w grupie badanej nie zaobserwowano działań niepożądanych. Efekty badania były wynikiem omijania przez 5-MTHF szlaku aktywacji folianów przez enzym MTHFR, który w przypadku grupy badanej był nieprawidłowy. Ponadto stosowanie 5-MTHF nie wiązało się z ryzykiem powikłań związanych zt zw. nadmiarem niezmetabolizowanego kwasu foliowego (unmetabolized folic acid, UMFA), jak dysfunkcja układu immunologicznego czy wzrost ryzyka raka okrężnicy i prostaty [11]. Zatem $\mathrm{w}$ grupie pacjentek $\mathrm{z}$ mutacją w genie MTHFR zaleca się przyjmowanie preparatów 5-MTHF.

\section{Niedobór i nadmiar kwasu foliowego w organizmie}

Niedobory folianów w codziennej diecie zwiększają ryzyko rozwoju wielu patologii, w tym miażdżycy, chorób sercowo-naczyniowych, niedokrwistości megaloblastycznej, nowotworów i chorób o podłożu neurodegeneracyjnym. W położnictwie wiążą się przede wszystkim z ryzykiem występowania nawracających poronień, preeklampsji czy porodu przedwczesnego. Jednak najistotniejszą konsekwencją niedoboru kwasu foliowego w okresie prokreacyjnym jest wzrost ryzyka wystąpienia wrodzonych wad rozwojowych nie tylko układu nerwowego, ale również sercowo-naczyniowego czy moczowo-płciowego. Należy jednak podkreślić, że zbyt duże dawki kwasu foliowego również mogą wpływać negatywnie na organizm. Zwiększone dawki kwasu foliowego mogą powodować bezsenność, rozdrażnienie, depresję, skórne reakcje alergiczne czy zaburzenia żołądkowo-jelitowe.

Wiele badań zwraca uwagę na potencjalny wpływ kwasu foliowego suplementowanego w czasie ciąży na choroby układu oddechowego. Whitrow i wsp. przedstawili wyniki badań, w których podaż kwasu foliowego w okresie ciąży wiązała się $\mathrm{z}$ istotnie większym ryzykiem rozwoju astmy u dzieci w wieku 3,5 lat oraz 5,5 lat [12]. Z kolei badania Trivedi i wsp. dowiodły braku korelacji między przyjmowaniem kwasu foliowego w ciąży a wzrostem ryzyka rozwoju astmy w dzieciństwie [13]. Do podobnych wniosków doszli w swoim badaniu Vereen 
i wsp., którzy nie wykazali związku pomiędzy mierzonym poziomem kwasu foliowego w II trymestrze ciąży a wzrostem ryzyka zachorowania na choroby układu oddechowego [14]. Powyższe dane w sposób niejednoznaczny oceniają wpływ witaminy B9 na rozwój chorób układu oddechowego. $Z$ tego powodu należy kontynuować tego typu badania, które pozwoliłyby na doprecyzowanie zaleceń dotyczących suplementacji kwasu foliowego w okresie ciąży.

\section{Układ nerwowy}

Zwiększone zapotrzebowanie na kwas foliowy występuje w szczególności w okresie ciąży i laktacji. Z tego powodu zalecenia wskazują na rozpoczęcie suplementacji kwasem foliowym już na 12 tygodni przed planowanym poczęciem. Niedostateczna podaż folianów może być przyczyną wrodzonych wad rozwojowych u płodu. Są one wynikiem nieprawidłowej biosyntezy DNA, bez którego żadna komórka nie jest w stanie zrealizować swojego cyklu metabolicznego, w tym podziału i różnicowania się. Należy nadmienić, że nie tylko niedostateczna podaż w codziennej diecie, ale również niewłaściwa bioprzyswajalność oraz genetycznie uwarunkowane nieprawidłowości w metabolizmie prowadzą do niedoborów folianów. Znaczące jest działanie kwasu foliowego na zmniejszenie częstości występowania wad dysraficznych $[15,16]$. Wynikają one z nieprawidłowego zamykania się cewy nerwowej w okresie zarodkowym, który następuje we wczesnym okresie ciąży (3-4 tydzień). Jest to zarazem "gorący okres”, w którym kobiety nie wiedzą albo dopiero dowiadują się o ciąży. Rozpoczęcie suplementacji kwasem foliowym w tym czasie zmniejsza szansę uniknięcia rozwoju wad układu nerwowego u płodu. $Z$ tego powodu tak ważna jest wcześniejsza suplementacja witaminami, a w szczególności folianów. Szacuje się, że w Polsce częstość występowania wad dysraficznych wynosi 2-3 przypadków na 1000 urodzeń. Jednak sa to dane epidemiologiczne odnoszące się przede wszystkim do przepuklin rdzeniowych oraz przepuklin mózgowych [17]. Jedną z najpoważniejszych wad cewy nerwowej jest bezmózgowie, które prowadzi do obumarcia płodu. Natomiast najczęstszą wadą układu nerwowego jest rozszczep kręgosłupa, który wiąże się z wieloma powikłaniami dla dziecka w konsekwencji prowadząc do trwałej niepełnosprawności. Polska ma największy odsetek umieralności z powodu wrodzonych wad cewy nerwowej na tle Europy. Jest to jednocześnie sygnał do podjęcia intensywniejszych działań mających na celu poprawę tej sytuacji epidemiologicznej. Badania własne o charakterze ankietowym przeprowadzone w Polsce w okresie od stycznia do kwietnia 2018 roku miały na celu zobrazowanie aktualnego stanu wiedzy młodych kobiet na temat konieczności suplementacji kwasu foliowego. Autorski kwestionariusz ankiety był rozprowadzony za pośrednictwem social media. Badanie objęło łącznie 961 respondentek, z których najliczniejszą grupę stanowiły kobiety w wieku $18-25$ lat $(80 \%)$. W odpowiedzi na pytanie dotyczące rekomendowanej dawki kwasu foliowego niespełna 38\% respondentek wskazywało właściwą dawkę 0,4 mg/dzień. Kolejne pytanie odnosiło się do okresu, w którym kobieta powinna suplementować foliany.
Tylko połowa kobiet wiedziała, w którym okresie należy suplementować kwas foliowy. Ponadto $72 \%$ kobiet nie stosuje rekomendowanej dawki witaminy B9 w okresie rozrodczym. Jedyne 34\% respondentek wie, że jednym z czynników wpływających na obniżenie poziomu witaminy B9 w organizmie jest stosowanie doustnych środków antykoncepcyjnych. Powyższe dane jednoznacznie wskazują na niedostateczną wiedzę młodych Polek w zakresie suplementacji folianów. Z jednej strony wynika to $\mathrm{z}$ braku właściwego rozpowszechnienia informacji o skuteczności kwasu foliowego w zapobieganiu wrodzonych wad rozwojowych. Z drugiej jednak część preparatów dostępnych na rynku farmaceutycznym nie zawiera odpowiednich dawek czy składu witamin. W niektórych krajach kwas foliowy jest obligatoryjnie dodawany do pożywienia m.in. chleba, co stanowi uzasadnioną profilaktykę wrodzonych wad rozwojowych, a w szczególności wad dysraficznych. W Polsce wciąż zbyt wiele kobiet dowiaduje się o konieczności suplementacji dopiero od swojego lekarza i zazwyczaj jest już zbyt późno na zminimalizowanie ryzyka wystąpienia wad układu nerwowego. $Z$ tego powodu ważne jest, aby upowszechniać, głównie wśród młodych kobiet w okresie rozrodczym, informacje o pozytywnych skutkach regularnego i codziennego stosowania kwasu foliowego. Kwas foliowy należy do witamin i powinien być zażywany niezależnie od rodzaju diety kobiety, ponieważ jest niezbędnym elementem do sprawnego funkcjonowania każdej komórki organizmu. Mimo licznych badań i ankiet prowadzonych na temat właściwej suplementacji kwasu foliowego w Polsce nadal wiedza dotycząca tego tematu jest niesatysfakcjonująca. Pośrednio może się to przekładać na częstość występowania wrodzonych wad układu nerwowego w naszym kraju. Na tej podstawie decyzja o przeprowadzeniu kolejnych badań ankietowych wydaje się jak najbardziej uzasadniona.

\section{Układ sercowo - naczyniowy}

Protekcyjne działanie kwasu foliowego nie wiąże się jedynie z układem nerwowym. Badania wskazują również na udział witaminy B9 w zapobieganiu wrodzonych wad serca (congenital heart defects, CHDs) [18,19]. Na świecie częstość ich występowania szacuje się na 0,6-1,9 na 100 noworodków [20]. Obszerna analiza przeprowadzona przez Beynum i wsp. dowiodła, że przyjmowanie kwasu foliowego przez kobiety w okresie okołokoncepcyjnym wiązało się z 20\% niższym ryzykiem wystąpienia u ich potomstwa CHDs. W szczególności dotyczyło to wad ubytku przegrody międzykomorowej (ventricular septal defect, VSD) oraz ubytku przegrody międzyprzedsionkowej typu secundum (antrial septal defect, ASD) [20].

\section{Układ moczowo - płciowy}

Wpływ witaminy B9 na zapobieganie wadom rozwojowym układu moczowego jest niejednoznaczny. Niektóre badania dowodzą, że suplementacja kwasem foliowym zwiększa ryzyko ich rozwoju. Kwestionariusz ankiety Groen in 't Woud i wsp. przeprowadzony wśród 562 rodziców dzieci z wrodzonymi wadami układu moczowego i 2139 rodziców dzieci zdrowych wskazuje, że kwas foliowy może być czynnikiem ryzyka rozwoju wad 
układu moczowego, a w szczególności zdwojenia układu kielichowo-miedniczkowego oraz odpływu pęcherzowo-moczowodowego [21]. Jednak należy podkreślić, że powyższe zależności były związane z przyjmowaniem przez kobiety kwasu foliowego niezwiązanego lub związanego z preparatami wielowitaminowymi. Bowiem to samo badanie wykazało, że przyjmowanie samych preparatów wielowitaminowych bez dodatkowej suplementacji kwasem foliowym wiąże się z nieznacznym zmniejszeniem ryzyka wrodzonych wad układu moczowego. $Z$ kolei badanie Canfield i wsp. wykazało brak negatywnego wpływu przyjmowanego przez kobiety kwasu foliowego (nie w formie wielowitaminowej) na rozwój wad układu moczowego [22]. Godwin i wsp. w swoim badaniu odnotowali wzrost częstości obturacyjnych wad układ moczowo-płciowego u dzieci kobiet spożywających produkty wzbogacone o kwas foliowy [23].

\section{Inne wrodzone wady rozwojowe}

Ponadto przypuszcza się, że prawidłowa suplementacja kwasem foliowym może zmniejszać ryzyko urodzenia dziecka z rozszczepem twarzoczaszki. Istnieją także doniesienia wskazujące na rolę kwasu foliowego w zapobieganiu wad kończyn,wrodzonego zarośnięcia odbytu, wrodzonego zwężenia odźwiernika, spodziectwa, polidaktylii czy syndaktylii.

\section{PODSUMOWANIE}

Zaleca się podawanie kwasu foliowego w sposób naturalny (produkty zawierające witaminę B9) lub w suplementach wielowitaminowych $\mathrm{z}$ uwagi na jego niedostateczną syntezę w komórkach. W celu zminimalizowania wystąpienia wrodzonych wad układu nerwowego PTGiP rekomenduje suplementowanie kwasu foliowego w dawce $0,4 \mathrm{mg} /$ dobę wszystkim kobietom w okresie rozrodczym na co najmniej 12 tygodni przed poczęciem, a następnie w czasie całej ciąży i w okresie laktacji. U kobiet w okresie ciąży chorujących na epilepsję zaleca się suplementację wyższymi dawkami folianów, które są uzależnione od stosowanych przez pacjentkę leków przeciwpadaczkowych. Natomiast kobiety z mutacją w zakresie genu MTHFR powinny stosować aktywne formy kwasu foliowego, jak 5-MTHF. Znaczenie kliniczne kwasu foliowego to przede wszystkim redukcja ryzyka występowania wrodzonych wad rozwojowych układu nerwowego, sercowo-naczyniowego oraz moczowo-płciowego. Jakkolwiek istnieją doniesienia o jego niekorzystnym działaniu m.in. w zakresie układu oddechowego (predysponuje do wystąpienia astmy).

\section{REFERENCES/PIŚMIENNICTWO}

1. Cieślik E., Kościej A. Kwas foliowy - występowanie i znaczenie. Probl Hig Epidemiol. 2012; 93(1): 1-7.

2. Bomba-0poń D, Hirnle L, Kalinka Ji wsp. Suplementacja folianów w okresie przedkoncepcyjnym, w ciąży i połogu. Rekomendacje Polskiego Towarzystwa Ginekologów i Położników. Gin Perinat Prakt. 2017; 2, 5: 210-214.

3. Paul L, Selhub J. Interaction between excess folate and low vitamin B12 status. Mol Aspects Med. 2017; 53: 43-47.
4. National Institutes of Health. Office of Dietary Supplemensts. Folate. Fact Sheet for Health Professionals. https://ods.od.nih.gov/factsheets/Folate-HealthProfessional/. Dostęp: 25.02.2019.

5. Kerr SM, Parker SE, Mitchell AA et al. Periconceptional maternal fever, folic acid intake, and the risk for neural tube defects. Ann Epidemiol. 2017: 27(12); 777-782.

6. Putta S, Pennell PB. Management of epilepsy during pregnancy: evidence-based strategies. Future Neurol. 2015; 10 (2): 161-176.

7. Viale L, Allotey J, Cheong-See F et al. Epilepsy in pregnancy and reproductive outcomes: a systematic review and meta-analysis. Lancet. 2015; 386(10006): $1845-1852$.

8. Gooneratne I.K, Wimalaratna M, Ranaweera AKP et al. Contraception advice for women with epilepsy. BMJ. 2017; 357:j2010.

9. Van Gool JD, Hirche H, Lax H et al. Folic acid and primary prevention of neural tube defects: A review. Reprod Toxicol. 2018; 80:73-84.

10. Turgal M, Gumruk F, Karaagaoglu E et al. Methylenetetrahydrofolate Reductase Polymorphisms and Pregnancy Outcome. Geburtshilfe Frauenheilkde. 2018: 78(09); 871-878.

11. Servy EJ, Jacquesson-Fournols $L$, Cohen $M$ et al.MTHFR isoform carriers. 5-MTHF (5-methyl tetrahydrofolate) vs folic acid: a key to pregnancy outcome: a case series. J Assist Reprod Genet. 2018: 35(8); 1431-1435.

12. Whitrow MJ., Moore VM., Rumbold AR. et al. Effect of Supplemental Folic Acid in Pregnancy on Childhood Asthma: A Prospective Birth Cohort Study. Am J Epidemiol. 2009; 170(12): 1486-1493.

13. Trivedi MK., Sharma S., Rifas-Shiman SL. Et al. Folic Acid in Pregnancy and Childhood Asthma: A US Cohort. Clin Pediatr. 2018; 57(4): 421-427.

14. Vereen S., Gebretsadik T., Johnson N. Association Between Maternal 2nd Trimester Plasma Folate Levels and Infant Bronchiolitis. Matern Child Health J. 2018; 23(2): 164-172.

15. Imbard A, Benoist JF, Blom H. Neural Tube Defects, Folic Acid and Methylation. Int Environ Res Public Health. 2013: 10(9); 4352-4389.

16. Greene NDE, Copp AJ. Neural Tube Defects. Annu Rev Neurosci. 2014: 37(1); 221-242.

17. Bagłaj M. Wady dysraficzne: wielospecjalistyczne postępowanie. Stowarzyszenie na Rzecz Dzieci z Rzadkimi Chorobami Genetycznymi i Ich Rodzin Wspólnie. http:// wspolnie.org/wady-dysraficzne/. Dostęp: 25.02.2019.

18. Liu S, Joseph KS, Luo W et al. Effect of Folic Acid Food Fortification in Canada on Congenital Heart Disease Subtypes Clinical Perspective. Circulation. 2016: 134(9); 647-655.

19. Linask KK, Huhta J. Folate protection from congenital heart defects linked with canonical Wnt signaling and epigenetics. Curr Opin Pediatr. 2010: 22(5); 561-566.

20. Van Beynum IM, Kapusta L, Bakker MK et al. Protective effect of periconceptional folic acid supplements on the risk of congenital heart defects: a registry-based case-control study in the northern Netherlands. Eur Heart J. 2009: 31(4); 464-471.

21. Groen in't Woud S, Renkema KY, Schreuder MF et al. Maternal risk factors involved in specific congenital anomalies of the kidney and urinary tract: A case-control study. Birth Defects Res A Clin Mol Teratol. 2016: 106(7);596-603.

22. Canfield MA, Collins JS, Botto LD et al. Changes in the birth prevalence of selected birth defects after grain fortification wiht folic acid in the United States: Findings from a multi-state population-based study. Birth Defects Res A Clin Mol Teratol. 2005: 73(10): 679-689.

23. Godwin KA., Sibbald B., Bedard T et al. Changes in Frequencies of Select Congenital Anomalies since the Onset of Folic Acid Fortification in a Canadian Birth Defect Registry. Can J Public Health. 2008;99(4):271-5

Manuscript received/Praca zgłoszona do czasopisma: 12.03.2019

Manuscript accepted/Praca zaakceptowana do druku: 03.04.2019

Translation/Tłumaczenie: Biuro Tłumaczeń Niuans 